\title{
Variability, heritability and genetic advance in indigenous and exotic okra [Abelmoschus esculentus (L.) moench] genotypes for yield and yield related traits at Dire Dawa, Eastern Ethiopia
}

\begin{abstract}
Okra [Abelmoschus esculentus (L.) Moench] is an annual vegetable that belongs to the family Malvaceae or Mallow. It is a warm-season annual herbaceous vegetable crop and it is self-pollinated, mainly propagated by seeds with maturity duration of 90-100 days. The plant is cultivated in tropical, subtropical, and warm temperate regions around the world. It was reported that okra is native to North Eastern Africa in the area of Ethiopia and Sudan. Therefore, this study was initiated with the objectives of estimating variability, heritability and genetic advance for indigenous okra collections and exotic commercial varieties for yield and yield related traits. The field experiment was conducted at Dire Dawa in 2016 using 25 okra genotypes (14 were indigenous collections and 11 exotic varieties) in $5 \times 5$ triple lattice design. Data were collected on 9 and 29 qualitative and quantitative traits, respectively. The phenotypic and genetic coefficients of variations ranged from 7 to 35.27 and 5.69 to $33.31 \%$, respectively. Heritability in broad sense ranged from $36.4 \%$ (days to maturity) to $99.3 \%$ (leaf width) while the genetic advance as percent of mean ranged from 7.7 (days to emergence) to $65.15 \%$ (tender fruits mucilage content), respectively. Both heritability and genetic advance as percent of mean values were high and moderate for all traits except for days to emergence which had moderate heritability and low genetic advance.
\end{abstract}

Volume 5 Issue 4 - 2020

\begin{abstract}
Anteneh Bekele Melaku, Wassu Mohamed, Vasantha Kumar

Lecturer, School of Plant Sciences, Haramaya University, Ethiopia
\end{abstract}

Correspondence: Anteneh Bekele Melaku, Lecturer, School of Plant Sciences, Haramaya University, P.O.Box: 138, Dire Dawa, Ethiopia, Email yituloe@gmail.com

Received: June 25, 2020 | Published: August 10, 2020

Keywords: variability, genetic advance, heritability

\section{Introduction}

Okra [Abelmoschus esculentus (L.) Moench] is an annual vegetable that belongs to the family Malvaceae or Mallow. It is a warm-season annual herbaceous vegetable crop and it is self-pollinated, mainly propagated by seeds with maturity duration of 90-100 days. ${ }^{1}$ The plant is cultivated in tropical, subtropical, and warm temperate regions around the world. ${ }^{2,3}$ It was reported that okra is native to North Eastern Africa in the area of Ethiopia and Sudan.,5 Okra is grown primarily for its young immature green fruits and fresh leaves used in salads, soups and stews. Okra has great diversity in different parts of the country particularly in the Western lowlands (550-650 m.a.s.l) regions. ${ }^{6}$ Communities in Gambella and Beneshangul have been cultivating the crop for its fruit and leaf to use as a food and medicine for different diseases.

Ethiopian Institute of Biodiversity has collected okra germplasm from Western lowland regions of Ethiopian. There were also an attempt of collection by Pawe (PARI), Gambella (GARI) and Assosa (AARI) Agricultural Research Centers, but only few reports are available about variability in okra germplasm. ${ }^{7-9}$ Although information on characterization has great value for the improvement of the crop, the information regarding to the Ethiopian okra germplasm is either not accessible or simply unavailable. Breeders' attempt in improving the crop in terms of developing varieties for high yield and quality traits from core collections is almost negligible. ${ }^{8}$

Okra has a potential to play significant role in mitigating food insecurity and alleviate malnutrition in the country. However, not only in Ethiopia but throughout the world, okra has been considered a minor crop and no attention was paid to its improvement in research programs in the past. ${ }^{10}$ Therefore, it is necessary to characterize and evaluate okra collections from Ethiopian in comparison to exotic commercial varieties to determine their commercial potential and to generate genetic variability information that can be used to improve the crop. Therefore, this study was initiated to estimate the genetic variability, heritability and genetic advance among indigenous and exotic okra genotypes for tender fruit and various agro morphological traits in Ethiopian okra collections.

\section{Materials and methods}

\section{Description of the study area}

The study was conducted at Dire Dawa, 518 kilometers away from Addis Ababa. The altitude of Dire Dawa is 1260 meters above sea level ${ }^{11}$ and the mean annual temperatures range from $21.5^{\circ} \mathrm{C}$ (December) to $28.4^{\circ} \mathrm{C}$ (June). It is characterized by warm and dry climate with a relatively low level of precipitation. The site has two rain seasons; that is, a short rain season from March to April, and a long rain season that extends from August to September. The aggregate average annual rainfall that the site gets from these two seasons is about $604 \mathrm{~mm}$. The annual average humidity is $41.82 \%{ }^{12}$

\section{Treatments and experimental design}

A total of 25 genotypes were evaluated of which 14 were collected from different okra growing regions of Ethiopian and the remaining 11 were exotic okra varieties. Genotypes were planted in $5 \times 5$ triple lattice design. Each plot was $0.8 \mathrm{mx} 7.2 \mathrm{~m}\left(5.76 \mathrm{~m}^{2}\right)$ consisting of one row and a total of 12 plants per row or per plot. The spacing between plots and adjacent replications were 0.8 and $2 \mathrm{~m}$, respectively. Three 
seeds per hill were sown and thinned to one plant per hill when plants reached 3-4 leaves stage.

\section{Data collection}

International Plant Genetic Resources Institute ${ }^{6}$ descriptor list for okra species were used to record data on quantitative and qualitative traits. Quantitative traits were recorded from 10 plants per row leaving the two plants grown at both end of the row as border plants and to collect data for mature fruits traits and seed traits. Five randomly selected tender fruits from each harvest in each plot were used to record tender fruit traits.

\section{Data analysis}

Analysis of variance: The quantitative data were subjected to analysis of variance (ANOVA) computed with SAS statistical software (9.2). ${ }^{13}$ Descriptive statistics was used to describe qualitative data. The traits that exhibited significant mean squares in general ANOVA were further subjected to genetic analyses. Phenotypic and genotypic variance and coefficient of variation, heritability, and genetic advance were computed using the excel Microsoft program.

Phenotypic and genotypic variability: The phenotypic and genotypic variability of each quantitative trait were estimated in terms of phenotypic and genotypic variances and coefficients of variation. The phenotypic and genotypic coefficient of variation was computed using the formula suggested by Burton and de Vane ${ }^{14}$ as follows. PCV and GCV values were categorized as low, moderate, and high as indicated by Sivasubramaniah and Menon. ${ }^{15}$

Heritability and genetic advance: Broad sense heritability values were estimated using the formula adopted by Falconer and Mackay. ${ }^{16}$ The heritability percentage was categorized as low, moderate and high as suggested by Robinson et al. ${ }^{17}$ Genetic advance in absolute unit (GA) and as percent of the mean (GAM), assuming selection of superior $5 \%$ of the genotypes was estimated in accordance with the methods illustrated by Johnson et al. ${ }^{18}$ The GA as percent of mean was categorized as low, moderate and high as suggested by Johnson et al. ${ }^{18}$

\section{Results and discussion}

\section{Quantitative traits}

Analysis of variance: Analysis of variance results revealed highly significant $(\mathrm{P}<0.01)$ differences among 25 okra genotypes for 29 quantitative traits which indicated that the genotypes varied for all traits studied. This result suggested the higher chance of improvement to be made for the traits of interest in the selected genotypes. This study result is in agreement with Tesfa and Yosef ${ }^{19}$ and Mihretu et al. ${ }^{20}$ who found significant differences among okra genotypes tested for the measured quantitative traits. The results of current study and other researchers in Ethiopia showed that okra collections from different regions of the country had significant differences for all traits which suggest that selection could be implemented to identify genotypes with desirable traits.

Mean performance of genotypes: The result showed that the exotic okra varieties had the lowest days to first flowering, 50\% flowering, days to pod formation and days to maturity indicating that the varieties are early genotypes than the Ethiopian okra genotypes, except for days to emergence. This study result is in agreement with Muluken et al. ${ }^{9}$ who reported that the two exotic okra varieties had the lowest days to fruit set (pod formation), first flowering, days to $50 \%$ flowering and days to maturity in his experiment indicating the varieties were early as compared to Ethiopian okra collections. The okra collections from Ethiopia were superior over exotic commercial varieties for growth traits. In other words, okra collections from Ethiopia had vigorous growth as compared to the introduced exotic okra varieties. This result is supported by Muluken et al. ${ }^{9}$ who reported all okra collections (23) they evaluated from Ethiopia had higher mean values than the two exotic okra varieties for plant height, stem diameter, numbers of branches, number of internodes and number of epicalyx per flower.

Ethiopian collections had higher mean values than exotic genotypes for all tender fruit yield and yield components except one exotic variety (Kiran) which had high mean value for number of fruits per plant. This showed the higher chance of developing varieties for tender fruit yield and yield components in Ethiopia through collection and selection of okra genotypes with the desired traits.

Tesfa and Yosef ${ }^{19}$ supported this result that the highest mean values for fruit length, fruit diameter, average fruit weight, indicating the variability among okra collections from Ethiopia. Mihretu et al. ${ }^{7}$ also reported the same results that okra accessions collected from Gambella Regional State had wide range of mean values for 20 quantitative traits.

The result also indicated that some of the okra collections from Ethiopia had higher mean values for matured fruit traits, seed yield and tender fruit mucilage content than exotic varieties. This suggested that okra collections from Ethiopia are promising to be developed to variety for high seed yield and tender fruit mucilage than exotic commercial varieties. Similar result was reported by Muluken et al. ${ }^{9}$ that fresh weight of mature pods, number of seeds per pod and hundred seed weight had highest mean values. Tesfa and Yosef (2016) also reported the highest mean values for seeds per fruit.

\section{Variability components}

Phenotypic and genetic coefficient of variations: The PCV and GCV values ranged from 7 to $35.27 \%$ and 5.69 to $33.31 \%$, respectively. The lowest PCV and GCV values were observed for days to maturity and days to emergence, respectively (Table 1), while highest values for both PCV and GCV were observed for number of matured pods per plant (Table 2). The number of primary branches, tender fruit weight, tender fruit yield (tender fruit yield per plant, per plot and per hectare), number of matured pods, dry weight of matured pod and tender fruit mucilage had high values for both coefficients of variations. The GCV and PCV values for these traits ranged from 20.31 to 33.31 and 23.44 to $35.27 \%$, respectively. The differences between the values of GCV and PCV were low $<2 \%$ except for tender fruit yield per plot and yield per hectare as well as dry weight of matured pod. Muluken et al. ${ }^{9}$ who reported that the number of branches per plant, fruit length, fruit yield ha ${ }^{-1}$, number of mature pods per plant and fresh weight of mature pod per plant which had high values $(>20 \%)$ both for PCV and GCV; Mihretu et al..$^{20}$ who reported high values of PCV and GCV for days to maturity, plant height, stem diameter, internode number and, number of branches per plant, peduncle length, fruit length, average fruit weight, fruit diameter, number of pod per plant and fruit yield.

Plant height, number of internodes (Table 1), number of fruits per plant, fresh weight of matured pods, dry matter and number of seeds per pod (Table 2) had moderate GCV ranging from 16.57 to $19.77 \%$, whereas these traits had high PCV values ranging from 20.44 to $27.48 \%$. Both GCV and PCV values were moderate for stem diameter, Inter node length, leaf length, leaf width, peduncle length (Table 1), fruit diameter, fruit ridge and 100 seed weight (Table 2). The magnitude of the differences between GCV and PCV values were low $<3 \%$ for all traits, except 3.96 and $10.91 \%$ differences between the two for the number of internode and dry matter, respectively. This implies the low influence of environmental factors for the phenotypic expression 
of the traits and selection on the basis of phenotype expression might

diameter, peduncle length, fruit diameter, fruit ridges, and 100 seed leads to improvement. Muluken et al. ${ }^{9}$ reported similar result for stem

weight which had medium values for both coefficients of variations.

Table I Estimates of variability components for 14 phenology and growth traits of 25 okra genotypes evaluated at Dire Dawa in 2016

\begin{tabular}{|c|c|c|c|c|c|c|c|c|c|c|c|}
\hline Traits & Range & Mean & SE & $\sigma^{2} g$ & $\sigma^{2} e$ & $\sigma^{2} p$ & GCV & PCV & $\mathbf{H}_{2}(\%)$ & GA & GAM (\%) \\
\hline DEm & $7.00-9.00$ & 7.47 & 0.49 & 0.18 & 0.24 & 0.42 & 5.69 & 8.73 & 42.5 & 0.57 & 7.7 \\
\hline DFF & $36.33-49.33$ & 42.07 & 3.51 & 11.19 & 12.34 & 23.53 & 7.95 & 11.53 & 47.6 & 4.76 & 11.3 \\
\hline DFPF & $43.33-56.33$ & 48.36 & 1.94 & 9.57 & 3.78 & 13.35 & 6.4 & 7.56 & 71.7 & 5.4 & 11.2 \\
\hline DPF & $47.00-62.00$ & 53.55 & 2.03 & 12.43 & 4.13 & 16.56 & 6.58 & 7.6 & 75.1 & 6.3 & 11.8 \\
\hline DMa & $56.00-71.33$ & 62.61 & 2.1 & 14.77 & 4.43 & 19.2 & 6.14 & 7 & 76.9 & 6.96 & 11.1 \\
\hline $\mathrm{PH}(\mathrm{cm})$ & $36.47-151.33$ & 107.75 & 5.83 & 451.2 & 33.99 & 485.19 & $19.7 \mid$ & 20.44 & 93 & 42.26 & 39.2 \\
\hline StD (cm) & $1.31-2.28$ & 1.84 & 0.14 & 0.05 & 0.02 & 0.07 & 12.18 & 14.29 & 72.6 & 0.39 & 21.4 \\
\hline $\mathrm{NPBr}$ & $1.53-6.07$ & 3.84 & 0.36 & 0.93 & 0.13 & 1.06 & 25.12 & 26.79 & 87.9 & 1.87 & 48.6 \\
\hline $\mathrm{Nin}$ & $16.00-39.10$ & 23.98 & 2.96 & 17.13 & 8.77 & 25.9 & 17.26 & 21.22 & 66.1 & 6.94 & 29 \\
\hline InLe (cm) & $3.14-7.01$ & 4.89 & 0.28 & 1.94 & 0.08 & 0.73 & 16.44 & 17.43 & 89 & 1.56 & 32 \\
\hline LLe $(\mathrm{cm})$ & $13.89-24.93$ & 19.02 & 0.65 & 7.71 & 0.42 & 8.13 & 14.6 & 14.99 & 94.9 & 5.58 & 29.3 \\
\hline LWd (cm) & $12.53-30.43$ & 21.24 & 0.36 & 17.5 & 0.13 & 17.63 & 19.7 & 19.77 & 99.3 & 8.6 & 40.5 \\
\hline NEpy & $9.47-12.87$ & 11.17 & 0.22 & 0.63 & 0.05 & 0.68 & 7.1 & 7.37 & 92.8 & 1.58 & 14.1 \\
\hline PLe (cm) & $1.31-3.35$ & 2.29 & 0.13 & 0.48 & 0.02 & 0.18 & 17.47 & 18.53 & 88.9 & 0.78 & 34 \\
\hline
\end{tabular}

Dem, days to $50 \%$ emergence, DFF, days to first flowering, DFPF, days to $50 \%$ flowering, DPF, days to first pod formation, DMa, days to maturity, PH (cm), plant height in centimeter, StD $(\mathrm{cm})$, stem diameter in centimeter, NPBr, no. of primary branch, Nin, no. of inter node, InLe ( $\mathrm{cm})$, inter node length in centimeter, LLe $(\mathrm{cm})$, leaf length in centimeter, LWd $(\mathrm{cm})$, leaf width in centimeter, NEpy, no. of epicalyx, PLe $(\mathrm{cm})$, peduncle length in centimeter, SE, standard error, $\sigma^{2} \mathrm{p}$ phenotypic variance, $\sigma^{2} g$, genotypic variance, $\sigma^{2}$ e, error variance, $\mathrm{PCV}$, phenotypic coefficient of variations, GCV, genotypic coefficient of variations, $\mathrm{H}^{2}(\%)$, broad sense heritability in percent, GA, expected genetic advance and GAM (\%),= genetic advance as percent of the mean

Table 2 Estimates of variability components for I 5 fruit traits, tender fruit and seed yield of 25 okra genotypes evaluated at Dire Dawa in 2016

\begin{tabular}{|c|c|c|c|c|c|c|c|c|c|c|c|}
\hline Traits & Range & Mean & SE & $\sigma^{2} g$ & $\sigma^{2} e$ & $\sigma^{2} p$ & GCV & PCV & $\mathbf{H}_{2}(\%)$ & GA & GAM (\%) \\
\hline FLe (cm) & $6.88-13.19$ & 10.96 & 0.89 & 1.19 & 0.8 & 1.99 & 9.96 & 12.87 & 59.8 & 1.74 & 15.9 \\
\hline FD (cm) & I.78-3.55 & 2.28 & 0.1 & 0.1 & 0.01 & 0.11 & $|3.8|$ & 14.49 & 90.8 & 0.62 & 27.1 \\
\hline FWt (g) & $12.17-33.47$ & 22.9 & 1.42 & 25.16 & 2.02 & 27.17 & 21.91 & 22.77 & 92.6 & 9.96 & 43.5 \\
\hline NFPP & $12.13-59.87$ & 31.71 & 3.48 & 39.29 & 12.14 & 51.43 & 19.77 & 22.62 & 76.4 & 11.3 & 35.6 \\
\hline FR $(\mathrm{cm})$ & $5.03-8.44$ & 6.81 & 0.19 & 1 & 0.04 & 1.03 & 14.68 & 14.94 & 96.6 & 2.03 & 29.8 \\
\hline FYPP (kg) & $0.45-2.05$ & 1.16 & 0.11 & 0.14 & 0.01 & 0.15 & 32.26 & 33.39 & 93.3 & 0.75 & 64.3 \\
\hline FYPPI (kg) & $4.45-19.54$ & 11.35 & 1.34 & 12.3 & 1.79 & 14.09 & 30.9 & 33.07 & 87.3 & 6.76 & 59.6 \\
\hline FYPH (t/ha) & $9.27-41.79$ & 23.61 & 2.71 & 54.32 & 7.32 & 61.64 & 31.22 & 33.26 & 88.1 & 14.27 & 60.46 \\
\hline NMP & $5.00-27.50$ & 14.89 & 1.73 & 24.6 & 2.99 & 27.59 & 33.31 & 35.27 & 89.2 & 9.66 & 64.9 \\
\hline FWMP (g) & $28.40-96.44$ & 70.83 & 7.52 & 195.99 & 56.48 & 252.47 & 19.77 & 22.43 & 77.6 & 25.45 & 35.9 \\
\hline DWMP (g) & $24.20-85.16$ & 63.02 & 7.36 & 163.86 & 54.24 & 218.1 & 20.31 & 23.44 & 75.1 & 22.89 & 36.3 \\
\hline DM (\%) & $26.45-54.03$ & 34.57 & 7.58 & 32.8 & 57.42 & 90.22 & 16.57 & 27.48 & 36.4 & 7.12 & 20.6 \\
\hline NSPP & $41.00-124.33$ & 88.42 & 6.03 & 890.48 & 36.32 & 333.15 & 19.49 & 20.64 & 89.1 & 33.55 & 37.9 \\
\hline HSW (g) & $3.90-8.10$ & 6.12 & 0.37 & 2.78 & 0.14 & 1.07 & 15.73 & 16.88 & 86.9 & 1.85 & 30.25 \\
\hline MuCo (\%) & $4.00-25.33$ & 12.65 & 0.92 & 50.28 & 0.84 & 17.6 & 32.36 & 33.16 & 95.2 & 8.24 & 65.15 \\
\hline
\end{tabular}

FLe $(\mathrm{cm})$, fruit length in centimeter, FD (cm), fruit diameter in centimeter, FWt (g), fruit weight in gram, NFPP, no. of fruit/plant, FR, fruit ridge, FYPP (kg), fruit yield per plant in kilogram, FYPPI (kg), fruit yield per plot in kilogram, FYPH (t/ha), fruit yield per hectare in tones, NMP, no. of mature pod, FWMP (g), fresh weight of mature pod in gram, DWMP (g), dry weight of mature pod in gram, DM (\%), dry matter in percent, NSPP, no. of seed/plant, HSW (g), hundred seed weight in gram, MuCo (\%), mucilage content in percent, SE, standard error, $\sigma^{2}$ p, phenotypic variance, $\sigma^{2}$ g, genotypic variance, $\sigma^{2} e$, error variance, PCV, phenotypic coefficient of variations, GCV, genotypic coefficient of variations, $\mathrm{H}^{2}(\%)$, broad sense heritability in percent, GA, expected genetic advance and GAM (\%), genetic advance as percent of the mean 
The values of GCV and PCV were low for days to $50 \%$ emergence, days to first flowering, days to $50 \%$ flowering, days to pod formation, days to maturity, number of epicalyx and fruit length. This indicated the greater influence of environmental factors for the phenotypic expression of these traits. This suggested that it is difficult or practically impossible to exercise selection based on phenotypic performance of the genotypes to improve the traits. Similar result was reported by Muluken et al. ${ }^{9}$ for days to $50 \%$ emergence and number of epicalyx; by Mihretu et al. ${ }^{7}$ for number of epicalyx; by Thirupathi et $a .^{21}$ for days to $50 \%$ flowering and by Sibsankar et al. ${ }^{22}$ for days to first flowering which had low values for both phenotypic and genotypic coefficients of variations.

Estimates of heritability and genetic advance: Heritability in broad sense $\left(\mathrm{H}^{2}\right)$ ranged from 36.4 (days to maturity) to $99.3 \%$ (leaf width), while genetic advance as percent of mean (GAM) ranged from $7.7 \%$ (days to emergence) to $65.15 \%$ (tender fruits mucilage content) (Table 1 and 2). It was suggested that considering both the genetic advance and heritability of traits rather than considering them separately is important in determining how much progress could be made through selection. ${ }^{18}$ Accordingly, high values were obtained both for heritability in broad sense and genetic advance as percent of mean for growth traits viz. plant height, stem diameter, number of primary branches, number of internode, internode length, leaf length, leaf width and peduncle length (Table 1). High heritability along with moderate genetic advance was observed for days to $50 \%$ flowering, days to pod formation, days to maturity, and number of epicalyx.

Both $\mathrm{H}^{2}$ and GAM values were high for tender fruit yields (yield per plant, yield per plot and yield per hectare), number of fruit per plant, fruit weight and fruit ridge. The matured fruit traits; fresh weight of matured pod, dry weight of matured pod, fruit diameter and number of matured pod also had high values for both $\mathrm{H}^{2}$ and GAM. Number of seeds per pod, 100 seed weight and tender fruits mucilage content also exhibited high values for both $\mathrm{H}^{2}$ and GAM (Table 2). In this study, high heritability coupled with high genetic advance for most of the traits suggested that improvement of these traits in genotypic value is rewarding in one cycle of selection in the new population compared with the base population. The high heritability of a trait is an indication of the fairly easy for selection because; there would be a close correspondence between the genotypic and phenotypic variations due to relatively small contribution of the environment to the phenotype expression of the trait. ${ }^{23}$ High genetic advance indicates that traits are controlled by additive genes. ${ }^{24}$ Heritability estimates along with genetic advance were more useful in predicting the effect of selecting the best individuals. ${ }^{18}$ It provides better information than each parameter alone and also an expression of additive gene action. ${ }^{22}$ This result is in agreement with Muluken et al. ${ }^{9}$ who reported high heritability and genetic advance for plant height, number of primary branches per plant, fruit weight, tender fruit yield $\left(\mathrm{t} \mathrm{ha}^{-1}\right)$, and fresh weight of mature pod per plant. This study result also supported by Mihretu et al. ${ }^{20}$ who reported high heritability and genetic advance values for internode length, number of primary branches, number of pods per plant, fruit length and diameter, average fruit weight, plant height, and fruit yield.

The values of heritability and genetic advance were moderate for days to first flowering and fruit length. Moderate heritability and high genetic advance was observed for dry matter while moderate heritability and low genetic advance was found for days to emergence. The moderate heritability and genetic advance might be due to the considerable influence of environmental factors on the expression of these traits. The results suggested that selection of genotypes based on the mean values for these traits might not be rewarding in one cycle of selection. Therefore, selection might be delayed to more advance generations for the traits that exhibited moderate heritability and genetic advance.

This result is supported by Muluken et al. ${ }^{9}$ and Chandramouli et al. ${ }^{25}$ who reported moderate heritability and genetic advance for days to first flowering and fruit length, respectively. In contrast this study results, Chandramouli et al. ${ }^{25}$ for plant height, Muluken et al. ${ }^{9}$ for internode length, Mihretu et al. ${ }^{7}$ for number of ridge and Adeoluwa and Kehinde ${ }^{26}$ for number of ridge and number of pod per plant reported low heritability and genetic advance.

\section{Qualitative traits}

The qualitative traits evaluated in this study include colour, shape and other features listed in Table 3 . These descriptors tend to be highly subjective. ${ }^{27}$ The variation in leaf shape, leaf color, petiole color, stem color, fruit color and fruit shape, among others, were easily recognizable with visual appraisal.

Table 3 Nine Qualitative traits variations among 25 okra genotypes evaluated at Dire Dawa in 2016

\begin{tabular}{lllllllllll}
\hline No. & Genotypes & PHa & FC & LC & LPC & PC & SC & LSh & FPo & FSh \\
\hline I & Mythri & 2 & 2 & I & 2 & I & I & 4 & I & 3 \\
2 & T240600 & 2 & 2 & 2 & 2 & 2 & 3 & 7 & I & 4 \\
3 & Guba 47 & 3 & 2 & 2 & 3 & 2 & 3 & 4 & 2 & 3 \\
4 & Guba 12 & 3 & 2 & 2 & 2 & I & 3 & 7 & I & I \\
5 & ArkaAnamica & 2 & I & I & I & I & I & 2 & I & 3 \\
6 & NamdHari & 2 & 2 & I & 2 & I & 3 & 7 & I & 4 \\
7 & Dangur 40 & 3 & 2 & I & I & I & 2 & 7 & I & 3 \\
8 & Clemson & 3 & 2 & I & 2 & I & 2 & 7 & I & 4 \\
9 & T240204 & 3 & 2 & 2 & 3 & 2 & 3 & 4 & 2 & 4 \\
10 & Dhenu & 2 & 2 & 2 & 2 & I & I & 4 & I & 3 \\
II & Vellayani & 3 & 2 & 2 & 2 & I & 2 & 7 & I & 4 \\
12 & Guba 21 & 3 & 2 & 2 & 2 & I & 2 & 7 & I & 12 \\
\hline
\end{tabular}


Table continued.

\begin{tabular}{lllllllllll}
\hline No. & Genotypes & PHa & FC & LC & LPC & PC & SC & LSh & FPo & FSh \\
\hline 13 & Guba 04 & 3 & 2 & 2 & 2 & 2 & I & 3 & I & 4 \\
14 & T240609 & 2 & 2 & 2 & 2 & I & 2 & 3 & I & I \\
15 & Guba 05 & I & I & I & I & I & I & 4 & I & 3 \\
16 & Anoop & I & 2 & I & 2 & I & 2 & 7 & I & 4 \\
17 & T242443 & 3 & 2 & 2 & 2 & I & 2 & 3 & I & 3 \\
18 & SOH 70I & 2 & 2 & 2 & 2 & I & 2 & 7 & I & 3 \\
19 & SOH 7I4 & 2 & 2 & 2 & 2 & I & 2 & 7 & I & 3 \\
20 & Arcanamica & 2 & 2 & I & I & I & I & 7 & I & 4 \\
21 & Guba 08 & 2 & 2 & 2 & 2 & I & 3 & 3 & I & 3 \\
22 & Guba 14 & 2 & I & I & 2 & I & 2 & 7 & I & 6 \\
23 & Kiran & 2 & 2 & I & 2 & I & 2 & 7 & I & I \\
24 & Guba 07 & I & 2 & 2 & 2 & I & 3 & 3 & 2 & 4 \\
25 & T242444 & 2 & 2 & 2 & 2 & I & 3 & 3 & 2 & 4 \\
\hline
\end{tabular}

PHa, plant habit, FC, flower color, LC, leave color, LPC, leave petiole color, PC, pod color, SC, stem color, LSh, leaf shape, FPo, fruit position, FSh, fruit shape

Plant habit: Thirteen (52\%) genotypes had densely branched base (DBB) of which eight and five genotypes were from India and Ethiopia, respectively. Nine (36\%), of which 7 and 2 genotypes from Ethiopia and other countries, respectively, had densely branched all over (DBO). Two (8\%) collections obtained from Metekel (Ethiopia) and one (4\%) exotic had densely branched at apex (DBA). Muluken et al. ${ }^{9}$ reported that $92 \%, 4 \%$ and $4 \%$ of 25 okra genotypes had densely branched at base, densely branched all over the plants and nonbranched plant habit, respectively.

Color of flower, leaf, leaf petiole, pod and stem: The result showed that the okra genotypes showed variations for flower, leaf, petiole and stem colors which would allow breeders to identify genotypes when they need to use them in breeding activities. Tesfa and Yosef ${ }^{19}$ observed collections with different stems and petiole colours. Adeoluwa and Kehinde (2013) reported uniform green leaf color for okra accessions. Adeoluwa and Kehinde ${ }^{26}$ found strong relationship among flower, leaf and leaf petiole color than between pod and stem color. These may be as a result of one gene controlling the flower, leaf and leaf petiole color

The results also showed that many okra genotypes had fruits with green color which is preferable by consumers. The tender green fruit is often considered as the most important and economic part of okra production since it is utilized as vegetable throughout the world. ${ }^{28}$ Ahiakpa $^{29}$ and Oppong-Sekyere et al. ${ }^{30}$ reported that the predominant fruit color were green followed by yellowish green in okra genotypes they studied.

Fruits position on main stem, fruit and leaf shapes: The okra genotypes showed two distinct fruit positions on the main stem in which $84 \%$ and $16 \%$ of the genotypes had fruits positioned erect and intermediate on the main stem, respectively. Muluken et al. ${ }^{9}$ observed that $68 \%$ and $32 \%$ of accessions borne fruits positioned erect and intermediate on main stem, respectively.

Most of the okra genotypes ( $80 \%$ ), scored ' 3 ' and ' 4 ', each $40 \%$, while $12 \%, 4 \%$ and $4 \%$ genotypes scored ' 1 ', " 6 " and 12 , respectively. Muluken et al. ${ }^{9}$ reported accessions with fruit shapes scored as "1", "2", "3", "12", "14" and "15". In agreement with these authors,
Oppong-Sekyere et al. ${ }^{30}$ reported fruit shapes of different scores.

In this study the genotypes were categorized in to four distinct leaf shapes viz. heart shaped (4\%), broadly ovate $(24 \%)$, star shaped $(20 \%)$ and palmately lobed shape (52\%). Muluken et al. ${ }^{9}$ had studied 25 okra accessions which had heart shapes $(48 \%)$, broadly ovate shape $(28 \%)$, star shaped $(16 \%)$ and palmate $(8 \%)$ leaf shapes.

\section{Summary and conclusion}

The analysis of variance revealed highly significant $(\mathrm{P}<0.01)$ differences among genotypes for all quantitative traits. Tender fruit yield ranged from 9.27 to $41.79 \mathrm{t} \mathrm{ha}^{-1}$. The okra collections from Ethiopia performed better for desirable tender fruits traits, mature fruit and seed yield as well as tender fruit mucilage content than the exotic varieties. The results showed the higher chance of developing okra varieties by selection of genotypes among okra collections from Ethiopia. Okra collections from Ethiopia had vigorous growth and most of the collections were superior to exotic commercial varieties for growth traits. The okra genotypes showed a broad variation for qualitative traits, which will be used for the identification of promising genotypes in okra breeding.

All genetic variability components (phenotypic and genetic coefficient of variations, heritability and genetic advance) values were high for number of branches, fruit weight, fruit yield per plant, per plot and per hectare, number of mature pods, dry weight of mature pods, and tender fruits mucilage content. The values of these variability components were high to medium for other 14 traits. The differences between the values of genetic and phenotypic coefficient of variations were low $<2 \%$ for all these traits except tender fruit yield per plot and hectare as well as dry weight of matured pod. In addition, both Heritability and genetic advance as percent of mean values were high to all these traits. The results showed that most of the quantitative traits were highly heritable and less influenced by environmental factors which suggested selection based on phenotype of the genotypes could be effective in improvement of these traits.

The results of this study revealed the presence of wide variation among okra genotypes that could be exploited to develop varieties in 
Ethiopia. The genotypes that had high tender fruit yield with desirable fruit quality traits could be promoted to multi-location test to develop varieties.

\section{Acknowledgments}

None.

\section{Funding}

None.

\section{Conflicts of interest}

The authors declare there are no conflicts of interest.

\section{References}

1. Tripathi KK, Govila OP, Ranjini W, et al. Biology of okra [Abelmoschus esculentus (L). (Moench]. Serious of crop specific biology document. Ministry of Environment and forests government of India and department of biotechnology ministry of science and technology government of India; 2011. 22 p.

2. Duzyaman E. Okra: botany and horticulture. Horticulture Reviews; $1997 ; 21: 41-72$

3. Yuan CY, Zhang C, Wang P, et al. Genetic diversity analysis of okra (Abelmoschus esculentus L.) by inter-simple sequence repeats (ISSR) markers. Genet Mol Res. 2014;13(2):3165-3175.

4. Aladele SE, Ariyo OJ, de Lapena R. Genetic relationships among West African okra (Abelmoschus caillei) and Asian genotypes (Abelmoschus esculentus) using RAPD. Afr J Biotech. 2008;7:1426-1431.

5. Santos BM, Dittmar PJ, Olson SM, et al. Okra Production in Florida. University of Florida IFAS extension; 2012:163-171.

6. IPGRI. Okra Descriptor list. International crop network series 5. Rome, Italy: International Board for plant Genetic Resources (IBPGR); 1991.

7. Mihretu Y, Weyessa G, Adugna D. Variability and association of quantitative traits among okra [Abelmoschus esculentus (L.) Moench] collection in South Western Ethiopia. Journal of Biological science. 2014;14:336-342.

8. Muluken D, Wassu M, Endale G. Genetic diversity of Ethiopian okra collection through multivariate analysis at Werer, Rift Valley of Ethiopia. The International Journal of Science \& Technoledge. 2015.

9. Muluken D, Wassu M, Endale G. Variability, heritability and genetic advance in Ethiopian Okra [Abelmoschus esculentus (L.) Monech] collections for tender fruit yield and other agro-morphological traits. Journal of Applied Life Sciences International. 2016;4(1):1-12.

10. Sanjeet K, Sokona D, Adamou H, et al. Okra (Abelmoschus spp.) in West and Central Africa: potential and progress on its improvement. African Journal of Agricultural Research. 2010;5(25):3590-3598.

11. Hailay DT, Marc L, Awash T, et al. Weather-based prediction of Plasmodium falciparum malaria in epidemic-prone regions of Ethiopia I. Patterns of lagged weather effects reflect biological mechanisms. Malaria Journal. 2004;3:41.

12. Levoyageur Weather: Djibouti. 2012.
13. SAS Institute. SAS /STAT Guide for personal computers, version 9.1 editions. Cary, NC, USA: SAS Institute Inc; 2008.

14. Burton GW, De Vane EH. Estimating heritability in tall fescue (Fistvea arundiancea) from replicated clonal material. Agriculture Journal. $1953 ; 45: 284-291$.

15. Sivasubramaniah, S, Meron M. Heterosis and in breeding depression in rice. Madras Agriculture Journal. 1973;60:1139-1144.

16. Falconer DS, Mackay TFC. An Introduction to Quantative genetics. Printice Hall London; 1996. 464 p.

17. Robinson HF, Comstock RE, Harvey PH. Estimates of heritability and the degree of dominance in maize. Agronomy Journal. 1955;41:353-359.

18. Johnson RW, Robinson HF, Comstock RE. Estimating genetic and environmental variability in soya bean. Agronomy Journal. 1955;47:314 318 .

19. Tesfa B, Yosef A. Characterization of Okra (Abelmoschus esculentus (L.) Moench) germplasms collected from Western Ethiopia. International Journal of Research in Agriculture and Forestry. 2016;3(2):11-17.

20. Mihretu Y, Weyessa G, Adugna D. Multivariate analysis among Okra [Abelmoschus esculentus (L.) Moench] Collection in South Western Ethiopia. Journal of Plant Sciences. 2014;9:43-50.

21. Thirupathi RM, Hari BK, Ganesh M, et al. Genetic variability analysis for the selection of elite genotypes based on pod yield and quality from the germplasm of okra [Abelmoschus esculentus (L.) Moench]. Journal of Agricultural Technology. 2012;8:639-655.

22. Sibsankar D, Arup C, Sankhendu BC, et al. Genetic parameters and path analysis of yield and its components in okra at different sowing dates in the Gangetic plains of eastern India. African Journal of Biotechnology. 2012;11(95):16132-16141.

23. Singh KB, Geletu B, Malhorta RS. Associatition of some traits with seed yield in chick pea collection. Euphytica. 1990;49:83-88.

24. Panse VG. Genetics of quantitative character in relation to plant breeding. Indian Journal of Genetics. 1957;17:317-328.

25. Chandramouli B, Shrihari1 D, Dorajee Rao AVD, et al. Studies on genetic variability, heritability and genetic advance in Okra [Abelmoschus esculentus (L.) Moench] genotypes. Plant Archives. 2016;16(2):679-682.

26. Adeoluwa OO, Kehinde OB. Genetic variability studies in West African okra (Abelmoschus caillei). Agriculture and Biology Journal of North America. 2011;2(10):1326-1335.

27. Hamon S, Van Sloten DH. Characterization and evaluation of okra. The Use of Plant Genetic Resources. 1989:173-196.

28. Eshiet AJ, Brisibe EA. Morphological characterization and yield traits analysis in some bselected varieties of Okra (Abelmoschus Esculentus L. Moench). Adv Crop Sci Tech. 2015;3:5.

29. Ahiakpa JK. Characterization of twenty-nine (29) genotypes of okra [Abelmoschus Spp (L.) Moench] in Ghana. Master of Philosophy, Ghana: University of Ghana; 2012.

30. Oppong-Sekyere D, Akromah R, Nyamah EY, et al. Characterization of okra (Abelmoschus spp. L.) germplasm based on morphological traits in Ghana. Journal of Plant Breeding and Crop Science. 2011;3(13):367-378. 